\title{
Evaluation of woody plants used by Pandam, Namu and Kayarda communities in tropical woody savanna, Nigeria
}

\author{
Unanaonwi, OkpoEsio ${ }^{1,}$, Amonum Joseph Igba' \\ ${ }^{1}$ Department of Biological Sciences, Federal University, Otuoke, NIGERIA \\ ${ }^{2}$ Department of Forest and Forest Productions,Federal University of Agriculture, Makurdi, NIGERIA
}

Email address:

okpoesio2002@yahoo.com(Unanaonwi,OkpoEsio), jamonng@yahoo.com(A. J. Igba)

\section{To cite this article:}

Unanaonwi, OkpoEsio, Amonum Joseph Igba. Evaluation of Woody Plants Used by Pandam, Namu and Kayarda Communities in Tropical Woody Savanna, Nigeria. Agriculture, Forestry and Fisheries. Vol. 2, No. 3, 2013, pp. 151-155.

doi: 10.11648/j.aff.20130203.15

\begin{abstract}
Most rural communities are opposed to forest reservation by the government not only because it denies them of the right of land ownership but because of the essential services these forests provide for the populace. In most cases there is usually total ban on any form of extraction from such forests without taking cognizance of the effects on those who live around these forests. The reason is because Government is not well informed of the rate of reliance of rural dwellers on the forests surrounding them. This research was conducted to ascertain the level of dependencies of three rural communities on Pandam Wildlife Park in Plateau State, Nigeria. Woody plants used by Pandam, Namu and Kayarda communities were investigated. A transect $(10 \mathrm{x} 1000)$ was laid across the park. Woody plants from $10 \mathrm{cmdbh}$ were marked. 12 people knowledgeable in plants and their uses were selected. They were made toidentify marked trees, their uses and parts used. Data were descriptively analyzed. Results show that $99 \%$ of identified plants have medicinal uses, 5 are used for food, 5 for economic purposes, 1 as first aid, 11 have multiple uses, 3 are under harvest pressure. Parts used are leave (37.10\%),bark $(30.65 \%)$. There is need for conservation especially those species (15) with multiple uses.
\end{abstract}

Keywords:Woody Plants, Plant Uses, Botanical Knowledge, Woody Savanna, Conservation

\section{Introduction}

Advances in modern medicine has prompted a renewed interest in the use of traditional medicine approach to meet health care needs of people all over the world especially rural dwellers of developing countries,thus making plants the spotlight [1]. It has been estimated [2] that about 70\% of the population in tropical Africa rely on the use of different plants to meet their health care services. Reference [3] stated that about $80 \%$ of the world's population use medicinal plants in the treatment of diseases. Various studies [4-7] have shown that indigenous food and medicinal plants play vital role in rural communities' livelihood, providing alternative source of nutrient and medicine.

There is quest for medicinal plants as majority of Nigerian especially rural dwellers depend on herbal medicines for treating variety of diseases. Most drugs of orthodox medicines are imported into Nigeria andare costly, giving room for sharp practices of collaboration between manufacturers and importers. The result is flooding the
Nigerian market with fake drugs which the Federal Government has been battling with over the years. Many studies on plants uses as food and medicine in Nigeria and other parts of West and South Africa are available but their publication for potential users, mostly the rural community dwellers are not readily available. Even when such publication is done, the names of plants are compiled in Latin, making it more difficult for the rural unlearned people to benefit from such work. It was on this backdrop that we undertake the involvement of the local people to draw from their knowledge of these plants, their local names and what they use them for.

There is an increasing inadequate access to western medicines and medical health personnel coupled with high cost of procurement which is beyond the reach of rural dwellers. This present reality has forced the people to look back into the forests around them, to draw from their local knowledge of the plants around them for immediate and cheap healthcare delivery. Bearing in mind that plants uses varies from one culture to another; we designed this study to investigate the local knowledge of the people about the 
plants around them with respect to usefulness in their lives, soas to serve as a blue- print for biodiversity conservation. We also believe that identifying the plants with their local names would be very useful to other members of the community who had been handicapped of the knowledge and could not meet their needs through the use of these plants.

\section{Materials and Methods}

\subsection{Study Site}

Pandam Wildlife Park was established in 1972 as a follow up to a white paper issued by the convention of African Heads of State (OAU) now African Union (AU) held at Kampala, Uganda in April, 1969. In the said OAU submit it was agreed by member states that one-third of their total land mass be made a green belt. A circular was subsequently issued by the then military Head of State General Yakubu Gowon( Rtd.), directing all the twelve states of the federation to make one-third of their land mass a green belt. In compliance, the then Benue-Plateau State Governor, Police Commissioner Joseph D. Gomwalk (Rtd.) employed the services of his former lecturer, a British consultant Zoologist Dr. Sylvia k. Sikes who eventually suggested Pandam forest as suitable for establishing a park. It was demarcated and all protocol completed and open to the public in July 1972 by General OlusegunObasanjo (Rtd).

The Park is situated within the middle belt of the Nigerian environment in the derived savanna zone. It is located north of the Benue River and south of Plateau State, along Lafia-Shendam Road in Quaan Pan Local Government Area of Plateau State. It lies between latitudes $80351 \mathrm{~N}$ and $8^{\circ} 551 \mathrm{~N}$, and longitudes $8^{\circ} 001 \mathrm{E}$ and $8^{\circ} 451$ E. The elevation is $155 \mathrm{~m}$ above sea level. Mean annual rainfall in the park is $105 \mathrm{~mm}$, mean annual temperature is $39^{\circ} \mathrm{C}$ and the mean humidity is 66 . Main occupation of the people is farming and hunting. The Park area is made up of three distinct habitats, the natural forest with an area of $244 \mathrm{~km} 2$, a riparian forest with an area of $22 \mathrm{~km} 2$ and savanna woodland with an area of $42 \mathrm{~km} 2$. Porosity and poor management has over the years subjected the Park to heavy human presence and pressure especially wood extraction and burning, as there is no buffer zone around the park.

\subsection{Sampling}

A transect belt of $10 \times 1000 \mathrm{~m}$ was demarcated from the forest area for studies according to the method of [8]. The transect belt was demarcated such that it cut across range of microclimates and plant species available in the park. The first step of investigation involved a botanist, two forest ecologist and three assistance who surveyed the woody plants from $10 \mathrm{~cm}$ diameter at breast height $(\mathrm{dbh})$ of $1.5 \mathrm{~m}$ and above within the transect. Plants of this category wereidentified, listed and marked at $1.5 \mathrm{~m}$ high with white paint for easy identification at subsequent time.

Second stage the of study involved contact with 12 people from the three communities ( 4 from each community on equal gender ratio) from age 45years and above who were identified to be well versed with local names of plants and their uses in their communities. Selection of the 12 people was based on the responses gotten from interactions with a broad section of the three communities who named them (the selected 12) as very good in plants names and uses. The age range of 45 years and above, and gender number equality of 6,6 , was used because younger people in a local community do not know names and uses of most plants around them, while women tend to know more of plants uses than men in a local community.

The third stage of investigation was plants identification by the selected people. In three different occasions at interval of two months, the 12 local people were individually taken to the forest and made to go through the laid transect belt. They were requested to identify all woody plants marked with white paints, giving their names, uses and part used, in the Hausa language, and also to comment on the status of the Park in terms of changes in vegetation structure and composition. Twelve different records were taken and finally compiled to produce a single record.

\subsection{Data Collection and Analysis}

Number of plants and species found, their local names, uses and plant parts used were among the data collected. These were subjected to descriptive analysis.

\section{Results and Discussion}

All over the world especially in the tropics, there is an existing relationship between the forest and local communities that surround the forest. For the Pandam, Namu and Kayarda communities, this relationship had existed long before the government took over the forest and gazette it as a Park in 1972. They depended solely on the forest for numerous supplies which include fuelwood, gums and resins, vegetables and fruit for food, building materials and crafts,as well as collection of plants parts for various health needs. We believe that the local community can value the forest and its resources better than the government if given what it requires. The results of this study is concerned with woody plants species from $10 \mathrm{~cm}$ $\mathrm{dbh}$ and was conducted between early September and late April which represents dry period in the southern guinea savanna of Nigeria. 26 woody plants species belonging to 15 families were encountered while number of individual species was ignored in the inventory. Names of species in the Hausa language were given in rhythm by the local participants (table 1). The knowledge ofplants' nameby the local people indicated that as long as a plant has a use value in the life of the people, there is a name of identity for such 
plant, other than mere description by flower,colour or leave shape.

All 12 participants gave the names of the identified plants very easily without contradiction. Ability of the rural community dwellers to identify plants by their local names is a strong indication of their knowledge, contact and use of these plants, as earlier pointed out by [9], where most rural household in Botswana depended on various natural resources for livelihoods.

\subsection{Uses of Woody Plant by Pandam, Namu and YardaCommunities}

Plants uses for various purposes that meet the needs of rural and urban populace have been mentioned but their uses vary from one community to another. The variation in uses is guided by factors such as culture, botanical knowledge, economic well-being, and access and proximity to the forests. Results from the three communities investigated (table 2) showed that all plants within the range of study serves useful purposes in the lives of the people. Uses include food, fuel wood, chewing stick, dye, stimulant and numerous medicinal uses. Medicinal uses mentioned include diabetes, cough, asthma, diarrhea, veneral diseases, pile, yellow fever, headache, malaria etc. These uses of plants by local communities have also been reported by [10-11, 7,12-13].

Lanneaacida in the familyAnacardiaceae was mentioned as being used in the replacement of loss energy. Replacement of loss energy is an important aspect of first aid especially among rural dwellers where there may be no medical doctor on ground to attend to emergency situations. The plant should in that case contain high level of glucose which though not the object of the present study, would be researched into. The pursuit to meet food needs of the world especially developing countries is still on. However, plants remain a major source of food, especially fruits, to rural communities. Notable species used in the study areas as food in form of fruits and vegetables include Adansoniadigitata, Afzelia Africana, Annonasenegalensis, Detariummarcrocarpum, Diospyrosomespiliformis and Vitexdoniana.

Rural livelihoods include their economic activities and apart from food supply, plants also provide means of engagement in economic activity for rural people. Results from the study (table 2) showed that some plant species are used in soap making and colouration (Sterculiasetigera and Cochlospermumplanchoni); as dye (Anogeissuslieocarpus); and for leather work (Combretum nigricans). Brideliaferruileais used as fragrant and as insect repellant. If harnessed through conservation and regulated harvest, these species could become potential economic resource base in these communities.

All woody plants investigated in the study except Afzeliaafricana, (25 or 99\% ) have medicinal uses, agreeing with [9] and [2].The indication therein is that health-care delivery is still a major problem faced by rural people who on the alternative make use of the plants around them.

Plants parts used by local communities include bark, seed, leave, root, latex or gum, fruit and twigs. The parts of a plant harvested and the methods of harvest have a long term impact on the ecological status of such species. Results of this study (table 3) showed that out of 62 recorded uses the leaf has the highest $(37.7 \%)$ number of uses in support of [2]. Following the leave is the bark which recorded $30.65 \%$ uses; the root $(12.9 \%)$; fruit $(8.06 \%)$; twigs and gum (4.84\%) each, and lastly seed which recorded $1.61 \%$ uses. Local communities have no better technique of harvesting the plant parts they intend to use. The leaves and twigs are cut, the bark is peeled off (debarking), and the roots are dug out and cut. These methods have grave consequences on species biodiversity and survival [14].

Defoliated plants especially in the dry season, as is usually the practice by the local communities, may die immediately. The species whose uses require debarking in this study (15), or their root dug up (4), are particularly in great danger irrespective of the season of harvest. The fastest way to kill a tree is to debark it. This causes accelerated water loss through evaporation which dries up the xylem vessels resulting to death. When roots are dug up and cut, there is cut in plant nutrient supply and loss of anchorage.

Woody plants with high number of uses have more than one plant part being harvested (table 3 ) and 11 out of the 26 species investigate fall under this category. Species like Annonasenegalensis; Anogeissuslieocarpu and Detariummarcrocarpum have three of their parts used (fruit, leaf, twig; leaf, twig, bark; and leaf, bark, fruit) which make them the most critical. If the branchesof trees are removed, and the bark peeled off, there are no chances of survival for such species and that is the situation with the afore-mentioned species. There is urgent need for conservation of these species not only for their uses but to prevent extinction through high exploitation demand due to their multiple uses.

\section{Conclusion}

The study provided opportunity to investigate local knowledge of plants and their uses by local communities who have no immediate access to modern facilities as obtained in the urban areas. A good knowledge of plants names and their uses were recorded indicating that the people have relationships with the plants in their immediate communities. Local people should on this basis be involved in managing forests around them, and should be allowed some monitored access to these forests as major part of their lives depends on plants use.

The study revealed that the highest use of plants in these communities is for medicinal uses and almost all the plants studied had more than one use in medicine. There is need to ascertain whether their heavy reliance on plants for 
health remedies is as a result of lack of attention by politicians;high cost of orthodox medicines; prejudice or for cultural reasons. Numerous uses of a single plant which results into the collection of many plant partsare impacting high extraction pressure on some species. This calls for urgent action towards conservation of these species even outside the park area to reduce pressure on the park.
There is opportunity for job creation for the people of these communities by the government, by embarking on large scale plantation of Sterculiasetigera and Cochlospermumplanchoni for soap making and colouration; Anogeissuslieocarpus to obtain dye; and Combretum nigricans for leather work.

Table 1.Useful Woody Plants according to local perception in Pandam Forest Reserve, Nigeria

\begin{tabular}{|c|c|c|}
\hline Species & Hausa Name & Family \\
\hline 1. Adansoniadigitata & Kuka & Bombacaceae \\
\hline 2. Afzelia Africana & Kawo & Caesalpiniacia \\
\hline 3. Annonasenegalensis & Gwandadaji & Annonaceae \\
\hline 4. Anogeissuslieocarpus & Marike & Combretaceae \\
\hline 5. Bombaxcostatum & Gurjiya & Bombacaceae \\
\hline 6. Brideliaferruilea & Ararrabi & Caesalpiniaceae \\
\hline 7. Burkeaafricana & Kureli & Caesalpiniaceae \\
\hline 8. Cochlospermumplanchoni & Rawaya & Cochlospermaceae \\
\hline 9. Combretum molle & Wuyandamo & Combretaceae \\
\hline 10. Combretum nigricans & CiririDagera & Combretaceae \\
\hline 11. Crossopteryxfebrifuga & KasiAwaki & Rubiaceae \\
\hline 12. Danielliaoliveri & Kadausa & Caesalpiniaceae \\
\hline 13. Detariummarcrocarpum & Taura & Caesalpiniaceae \\
\hline 14. Dispyrosmespiliformis & Kanya & Ebenaceae \\
\hline 15. Entadaafricana & Tawaosa & Mimosaceae \\
\hline 16. Fiscuscycomovus & Baure & Moraceae \\
\hline 17. Fiscusthonningii & Cediya & Moraceae \\
\hline 18. Khayasenegalensis & Madaci & Miliaceae \\
\hline 19. Kigeliaafricana & Rawuya & Bignoniacea \\
\hline 20. Lanneaacida & Faru & Anacardiaceae \\
\hline 21. Lanneaschimperi & Farudoya & Anacardiaceae \\
\hline 22. Pseudocedrelakotschyi & Tuna & Combrateceae \\
\hline 23. Sterculliasetigera & Kukuki & Sterculiceae \\
\hline 24. Strychnosspinosa & Kokiya & Loganiaceae \\
\hline 25. Tamarindusindica & Tsamiya & Casaelpiniaceae \\
\hline 26. Vitexdoniana & Diya & Verbenaceae \\
\hline
\end{tabular}

Table 2.Uses of woody plants found in Pandam forest Reserve according to local perception

\begin{tabular}{lll}
\hline Species & Uses & Plant Parts \\
\hline 1. Adansoniadigitata & Vegetable, cure for diabetes, cough and asthma. & L \\
2. Afzelia Africana & Vegetable. & L. \\
3. Annonasenegalensis & Edible fruit, cure for diarrhea \&veneral diseases. & F,L,T \\
4. Anogeissuslieocarpus & Chewing stick, cure for malaria, ulcer, as dye andtreatment of wound. & L,T,B. \\
5. Bombaxcostabums & Cure for pile, yellow fever, and headache. & L. \\
6.Brideliaferruilea & As fragrant, keep away insects, cure for stomachupset, diarrhea and fever. & L.R. \\
7. Burkea Africana & Treatment of wound; cures for diarrhea. & B. \\
8. Cochlospermumplanchoni & Cure for yellow fever, soap coloration. & R. \\
9. Combretum molle & Cure for stomach upset, gum collection for trade. & B,G. \\
10. Combretum nigricans & Cure for diarrhea, leather work. & B. \\
11. Crossoptrxfebrifuga & Cure for diarrhea, veneral diseases. & L. \\
12. Danielliaoliveri & Cure for high blood pressure. & B. \\
13. Detariummarcrocarpum & Edible fruit, cure for fever, aphrodisiac. & L,B,F \\
14. Diospyrosomespiliformis & Edible fruit, chewing stick,. & F.T. \\
15. Entada Africana & Cure for cough. & B. \\
16. Fiscuscycomovus & Cure for ring worm, stimulant to mammary gland. & G,B. \\
17. Fiscusthonningii & Cure for ringworm, stimulant to mammary gland. & G,B. \\
18. Khayasenegalensis & Cure for stomach ache, pile. & B.L. \\
19. Kigelia Africana & Cure for dysentery, Stomach ache, kidney pain. & L.
\end{tabular}




\begin{tabular}{lll}
\hline 20. Lanneaacida & Replaces loss energy, cure stomach-ache. & B. \\
21. Lanneaschimperi & Cure for snake bite, toothache, Chewing stick. & R,B. \\
22. Pseudocedrelakotschyi & Cure for malaria, stomach-ache, skin rashes. & L,B. \\
23. Sterculliasetigera & Soap making, cure for stomach-ache. & B,S. \\
24. Strychnosspinosa & Cure for stomach-ache. & R. \\
25. Tamarindusindica & Cure for body pain, treatment of wound. & L. \\
26. Vitexdoniana & Vegetable, edible fruit. & L.F. \\
\hline
\end{tabular}

Abbreviations for plant parts used:B = Bark, $\mathrm{S}=\mathrm{Seed}, \mathrm{L}=$ Leave, $\mathrm{R}=$ Root, $\mathrm{G}=\mathrm{Gum}$ (latex), $\mathrm{F}=$ Fruit, $\mathrm{T}=$ Twig (branches)

Table 3.Evaluation of Plants part used by local people of_Pandam, Namu and Kayarda Communities

\begin{tabular}{ccc}
\hline Plant Parts & Number of Uses & $\mathbf{\%}$ \\
\hline Bark & 19 & 30.65 \\
Fruit & 5 & 8.06 \\
Gum (latex) & 3 & 4.84 \\
Leave & 23 & 37.10 \\
Root & 8 & 12.90 \\
Seed & 1 & 1.61 \\
Twig (branches) & 3 & 4.84 \\
Total & 62 & 100 \\
\hline
\end{tabular}

\section{References}

[1] O. R. Adejoba,K.A.Bolaji-Olutunji, and A.O. Salami,Ethnobotany and Medicinal Utilization of Fiscusmucoso in Ibadan Metropolis in, Forestry in the Context of the Millenium Development Goals (eds.Popoola, L., Ogunsanwo, K. and Idumah, F.) Proceedings of $34^{\text {th }}$ Annual conference of the Forestry Association of Nigeria, $5^{\text {th }}-10^{\text {th }}$ December, 2011, Oshogho Nigeria.pp591-593.

[2] C. Gabaluzi, J. G Agea, B. L. Fungo, and R. M. Kamuga, R.M., Traditional Medicine as an alternative form of Healthcare system: A Preliminary case study of Nangabo SubCounty, Central Uganda. Afr. Jour. TraditioalComplimentary and Alternative Medicine.2010. 7(1) 11-16.

[3] World Health Organization (WHO), Traditional Medicines Facts Sheet Number 134 revised May,2003. http/www.who.int/mediacentre/factsheet/fs 134/en TRM/Geneva. Pp6.

[4] B. A. M. Scherrer, R. Motti, and C. S. Wednerie, Traditional plants use in the areas Monte Vesole and Asoea National Park (Campania, Southern Italy). Jour. Ethopharmacol.2010,97(1):129-143.
[5] J. E.M. Arnold, P.M. Ruiz, Can non-timber forest products match tropical forests conservation and development objectives? Ecol. Econ. 2004. 39:437-447.

[6] A. H. Ladio, M. Lozada, Patterns of use and knowledge of wild edible plants in distinct ecological environment: A case study of a Mapuche community in Patagonia. Biodiv. Conserv. 2004, 13(6) 1153-1173.

[7] C. M. Shacleton, S. E. Shacleton, The Importance of nontimber products in rural Livelihood security and as safetynets: A review of evidence from South Africa. South Afri. Jour. Sci., 2004. 100:658-664.

[8] G. J. Martin, Ethnobotany: People and Plants Conservation Manual. Chapman and Hall, London, 1995. Pp 268.

[9] G. M. Legwaila, W.Mojeremane, M. E. Madisa, R.M. Mmolotsi, and M.Rampart, Potentials of Traditional Food Plants rural household food security in Botswana.Jour. of Horticulture and Forestry 2011. Vol.3(6) pp171-177.

[10] B. O. Muok, A. Matsumura, A. Ishii, and D. W. Odes, The effect of Intercropping Sclerocaryabirrea (A. Rich.) Hocst, milet and corn in the presence of arbuscularmycorrhizalfungi.African Jour. of Biotechnology, 2009. 8(5):807-812.

[11] F. K.Akinnifesi, G. Seleshi, O. C. Ajayi,P.W.Chinwa, and R. Harawa, (2008a). Contributions of Agroforestry research and development to livelihood of small holder farmers in Southern Africa 2.Fruit, Medicinal, Fuelwood and fodder trees systems.Agric. Jour. 2008a. 3(1):76-88.

[12] E. Dounias, W. Rodrigues,andC.Petit, Review of the ethnobotanical Literature for Central and West Africa. Afr. Ethnobot. Netw. 2000. Bull. 2:5-117.

[13] P.M. Ruiz, O.Ndoye, and A. Eyebe, Marketing of nontimber forest products in the humid forest zone of Cameroon, Unasylva, 1999. 50:12-19.

[14] S.E. Shacleton, C.M. Shacleton, T.R. Netshiluvhi, B.S. Geach, A. Balance, and D.H.K. Fairbanks, Use parameters and value of Savanna resources in three rural villages in South Africa. Econ.Bot. 2002. 56(2):130-146. 